\title{
GENETIC DIVERSITY AND ANTIFUNGAL SUSCEPTIBILITY TESTING OF TRICHOSPORON ASAHII ISOLATED OF INTENSIVE CARE UNITS PATIENTS
}

\author{
Rosana Bellan de Oliveira Silva ${ }^{1,2}$; Ana Marisa Fusco-Almeida ${ }^{2}$; Marcelo Teruyuki Matsumotoº \\ Lilian Cristiane Baeza ${ }^{3}$; Tatiane Benaducci²; Maria José Soares Mendes-Giannini*
}

${ }^{1}$ Instituto Adolfo Lutz, Rio Claro, SP, Brasil; ${ }^{2}$ Departamento de Análises Clínicas, Faculdade de Ciências Farmacêuticas, Universidade Estadual Paulista, Araraquara, SP, Brasil; ${ }^{3}$ Universidade Estadual de Maringá, Maringá, PR, Brasil

Submitted: December 10, 2007; Returned to authors for corrections: February 08, 2007; Approved: July 05, 2008.

\begin{abstract}
Trichosporon asahii is an opportunistic pathogen, associated with a high mortality rate in immunocompromised patients. In this study, ten isolates, recovered from oral cavity and urine of patients in Intensive Care Units (ICU) over six months, were identified by classical and molecular methods, typed by RAPD and tested in vitro for susceptibility to fluconazole, itraconazole, 5-flucytosine and amphotericin B. A total agreement between the identification of Trichosporon sp by PCR based on sequences of the Internal Transcribed Spacer Regions (ITS) and on the sequences of small-subunit (SSU) ribosomal DNA (rDNA) was found. Randomly amplified of polymorphic DNA (RAPD), with primers P6 and M13, was used to determine the genomic profiles. The dendogram analysis indicated that almost all strains showed similarity $>0.9$ among them and all strains were multidrug-resistant. This study brings new results on the identification and genotyping of $T$. asahii isolated from Brazilian ICU patients and information about their antifungal drugs susceptibility.
\end{abstract}

Key-words: Trichosporon, PCR, RAPD, susceptibility, antifungal drugs

\section{INTRODUCTION}

In the past few decades, a worldwide increase in the incidence of fungal infections has been observed, as well as the recognition of innocuous yeasts, previously thought incapable of harming the human body, as pathogens (38). The emergence of less common but medically important fungal pathogens has contributed to the rate of morbidity and mortality, especially in the increasingly expanding population of immunocompromised patients. Various groups have stressed the importance of new opportunistic fungal pathogens as causes of life-threatening infections $(1,14)$. Among them, deep-seated trichosporonosis is a lethal opportunistic infection occasionally found in immunocompromised patients, particularly those who are neutropenic due to cytotoxic therapy for hematological malignancies.
Over the past decade, the taxonomy of the genus Trichosporon has been subjected to extensive revision on the basis of molecular data, and the previously named $T$. beigelii (or T. cutaneum) corresponds, in the most recent classification, to six different species: T. asahii, T. asteroides, T. cutaneum, T. inkin, T. mucoides, and T. ovoides $(15,16)$.

Trichosporon is found in the commensal mycobiota of the skin surface, mainly in the genito crural and perianal areas of homosexuals (47). This yeast is found in the normal skin, nails and mouth of healthy individuals $(28,35,58)$, as well as, in Brazil, T. asahii was also recovered from rice and cassava used in fermented beverages (45).

Trichosporon infections are rare but have been associated with a wide spectrum of clinical manifestations, ranging from superficial involvement in immunocompetent individuals such as white piedra $(40,47)$ to severe systemic disease in

*Corresponding Author. Mailing address: Laboratório de Micologia Clínica, Departamento de Análises Clínicas, Faculdade de Ciências Farmacêuticas, UNESP, Rua Expedicionários do Brasil, 1621, CEP 14801-902, Araraquara, SP, Brasil. Tel.: +55 (16) 33016556/ Fax: +55 (16) 33016547. E-mail: giannini@fcfar.unesp.br 
immunocompromised patients with a pattern similar to candidiasis $(6,19,29,30,43,58)$. Rodrigues et al. (43) described twenty-two cases of nosocomial infection caused by T. asahii, detected during a period of six years (1999-2005) in a Brazil hospital. Recently, a case was reported of systemic Trichosporon cutaneum infection in a 3-year-old infant with Wilms' tumor (5). In the same hospital, an oropharyngeal secretion sample was collected from an AIDS patient with oral lesions and Trichosporon pullulans was isolated (34).

At the moment, Trichosporon asahii is the most clinically important pathogenic yeast in the genus Trichosporon, as this species causes both deep-seated infection and summer-type hypersensivity pneumonitis $(9,15,17,28,49,52)$. Sugita et al. (49) have suggested that $T$. asahii is common environmental pathogen, and Martins-Diniz et al. (25) have also encountered this genus in both biotic (professional health) and abiotic sources (areas of hospital) with prevalence around 30\% among yeast isolated. Pini et al. (39) have found massive air contamination with $T$. asahii in the ward where neutropenic patients were staying and the corridor immediately outside.

Trichosporon infection is associated with high morbidity and mortality and is difficult to treat, frequently involving resistance to 5-fluorocytosine, azoles and amphotericin B $(10,41)$. Walsh et al. (57) noted that blood isolates were more resistant to amphotericin B than skin isolates. The optimal antifungal therapy for these infections is unclear. There is growing evidence that azole drugs have good activity against Trichosporon spp. $(3,11,36)$ and that combined administration of fluconazole and amphotericin B may be superior to either drug used alone against invasive infection $(2,18)$. Meyer et al. $(28)$ report a case of chronic disseminated $T$. asahii infection in a child with leukemia, where a cure was achieved after treatment with itraconazole.

The therapies are only effective if the disease is detected at an early stage, and, therefore, early diagnosis is an important factor in the successful management of patients with disseminated trichosporonosis. Unfortunately, difficulties in the identification of these microorganisms lead to delays in treatment and post-mortem diagnosis $(30,31)$.

Species identification and molecular typing have become critical elements of nosocomial fungal outbreak investigations. The studies should include the origins of nosocomial infection, genetic comparison between invasive or noninvasive isolates, and comparison of the genotypes and susceptibilities of the isolates (53).

Many investigations of the intraspecies diversity and epidemiology of pathogenic fungi using random amplified polymorphic DNA (RAPD) analysis, hybridization with specific probes such as CA3, and multilocus enzyme electrophoresis (MLEE) have been reported, but there are only a few reports for Trichosporon species $(12,48)$.

Sugita et al. (51) have sequenced the internal transcribed spacer (ITS) region and describe a rapid PCR-based approach for detection of all species of emerging yeasts of the Trichosporon genus. The PCR product length alone identified all the isolates, the primers TRF (forward) and TRR (reverse) being chosen to align with regions were not conserved in other medically important yeasts (50). Their data indicate that the PCR detection system is useful for identifying these yeasts.

In Brazil there are few survey on these yeasts $(30,34,43)$. In this study we examined the genetic diversity and biochemical characteristics of T.asahii strains recovered from clinical specimens (oral cavity and urine) from patients in Intensive Care Units (ICU), as well as the correlation between the drug susceptibility profile and genetic changes detected by RAPD (primer M13 and 6).

\section{MATERIALS AND METHODS}

\section{Yeast isolates}

All isolates were recovered from clinical specimens (two from oral cavity and eight from urine) from patients in Intensive Care Units (ICU), collected from April to September 2001. The isolates were subcultured on Sabouraud glucose agar (SGA). Isolates were identified by API 20C AUX (BioMérieux, France) strip in accordance with the manufacturer's instructions and by evaluation of their micromorphological features, on cornmeal Tween 80 -agar. The interpretation of the data was based on Kurtzman and Fell (21).

\section{Oligonucleotide primers and PCR amplification}

The internal transcribed spacer (ITS) regions were amplified with primers ITS $_{1}\left(5^{\prime}\right.$ - TCC GTA GGT GAACCT GCG G - 3') and ITS $_{4}\left(5^{\prime}\right.$ - TCC TCC GCT TAT TGA TAT GC - 3'), which were designed from conserved regions to amplify the $18 \mathrm{~S}$ rDNA, $25 \mathrm{~S}$ and 5,8S regions of ribosomal DNA (51). The primers, TRF (forward) (5'-AGA GGC CTA CCA TGG TAT CA- $3^{\prime}$ ) and TRR (reverse) (5' -TAA GAC CCA ATA GAG CCC TA- 3'), were chosen because they would specifically amplify only Trichosporon species and to align with regions which were not conserved in other medically important yeasts (50). These PCR primers correspond to nucleotides 154 to 173 and 354 to 335 of Saccharomyces cerevisiae SSU rDNA. For both PCRs, the amplification reactions were performed in $25 \mu \mathrm{L}$ sterile distilled water containing $1 \mu \mathrm{M}$ of each primer, $3.0 \mu \mathrm{L}$ of template DNA solution $(1.5 \mu \mathrm{g} / \mathrm{mL}), 1.5 \mathrm{mM} \mathrm{MgCl}_{2}, 2.5 \mathrm{U}$ of Taq polymerase, $200 \mu \mathrm{M}$ of each deoxynucleoside triphosphate (dNTP). The reaction mixtures were amplified in a Perkin-Elmer 9700 thermal cycler with following programs: for TRF/TRR, denaturation at $94^{\circ} \mathrm{C}$ for 3 min was followed by 30 cycles comprising denaturation at $94^{\circ} \mathrm{C}$ for $30 \mathrm{~s}$, annealing at $56^{\circ} \mathrm{C}$ for $15 \mathrm{~s}$ and amplification at $72^{\circ} \mathrm{C}$ for $15 \mathrm{~s}$, with a final extension period at $72^{\circ} \mathrm{C}$ for $10 \mathrm{~min}$, for the ITS region, $94^{\circ} \mathrm{C}$ for $3 \mathrm{~min}$ followed by 40 cycles of $94^{\circ} \mathrm{C}$ for $1 \mathrm{~min}$., $57^{\circ} \mathrm{C}$ for $1 \mathrm{~min}$. and $72^{\circ} \mathrm{C}$ for $2.5 \mathrm{~min}$., with a final $10 \mathrm{~min}$ period at $72^{\circ} \mathrm{C}$. After thermal cycling, $5 \mu \mathrm{L}$ of the amplified 
products were run on $2.0 \%$ agarose gel in $1 \times \mathrm{TBE}(90 \mathrm{mM}$ Tris, $90 \mathrm{mM}$ boric acid, $2 \mathrm{mM}$ EDTA pH 8) buffer for $150 \mathrm{~min}$ at $150 \mathrm{~V}$, stained with $0.5 \mu \mathrm{g} / \mathrm{mL}$ ethidium bromide (GIBCO), and visualized under UV light, with the aid of Image Master VDS (PHARMACIA BIOTECH), and photographed.

\section{RAPD analysis}

Genomic DNA was extracted and purified by a slight modification of the method of Lasker et al. (22). RAPD was carried out with primer 6 (5'-d[CCC GTC AGC A]-3'), (Amersham Pharmacia Biotech) and M13 (5'- d [GAG GGT GGC GGT TCT]-3'), in a total volume of $25 \mu \mathrm{L}$, using the Ready-ToGo RAPD Kit in accordance with the manufacturer's instructions. The following cycle conditions were used for primer 6: initial denaturation at $95^{\circ} \mathrm{C}$ for $5 \mathrm{~min}$, followed by 45 cycles of denaturation at $95^{\circ} \mathrm{C}$ for $1 \mathrm{~min}$, annealing at $36^{\circ} \mathrm{C}$ for 1 min and amplification at $72^{\circ} \mathrm{C}$ for $2 \mathrm{~min}$, with a final extension at $72^{\circ} \mathrm{C}$ for $10 \mathrm{~min}$. The cycle used for primer M13 was: initial denaturation at $94^{\circ} \mathrm{C}$ for $3 \mathrm{~min}$, followed by 40 cycles of denaturation at $94^{\circ} \mathrm{C}$ for $20 \mathrm{~s}$, annealing at $50^{\circ} \mathrm{C}$ for $1 \mathrm{~min}$, and amplification at $72^{\circ} \mathrm{C}$ for $20 \mathrm{~s}$ with a final extension at $72^{\circ} \mathrm{C}$ for 6 $\mathrm{min}$. Amplification products were separated by electrophoresis on $2 \%$ agarose gels in $1 \mathrm{X}$ TBE buffer $(0.1 \mathrm{M}$ Tris, $0.09 \mathrm{M}$ boric acid, $0.001 \mathrm{M} \mathrm{EDTA}$ [pH 8.4] at $150 \mathrm{~V}$ for $2.5 \mathrm{~h}$, stained with 0.5 $\mathrm{mg}$ of ethidium bromide per $\mathrm{mL}$ of deionized water for $30 \mathrm{~min}$., and then visualized under UV light and photographed. Patterns were analyzed both by visual comparison and by the Image Master VDS Software (Pharmacia Biotech). The computer program GelCompar II version 2.0 was used to determine the genetic relationship of the isolates. Similarity coefficients were calculated by the Dice Algorithm and cluster analysis was performed by an UPGMA algorithm (46).

\section{In vitro antifungal susceptibility testing}

The susceptibility testing followed the Clinical and Laboratory Standards Institute (CLSI) recommendations for microdilution procedures, but included modifications described previously $(7,44)$. Briefly, in the susceptibility test, RPMI 1640 supplemented with $2 \%$ glucose was inoculated with $2 \times 10^{5} \mathrm{CFU} /$ $\mathrm{mL}$, in the flat-bottomed wells of microplate cultures trays. All microplates were wrapped with film sealer to prevent the medium from evaporating, attached to an electrically-driven wheel inside the incubator, agitated at $350 \mathrm{rpm}$, and incubated at $35^{\circ} \mathrm{C}$ for 48 h. Candida parapsilosis (ATCC 22019) was used as the control strain. The antifungal agents used in the study were: amphotericin B (AMB) (Sigma Aldrich Quimica S.A.), 5fluorocytosine (5FC) (Sigma Aldrich), fluconazole (FCZ) (Pfizer S.A.) and itraconazole (ITZ) (Janssen S.A.). AMB, FCZ, and ITZ were dissolved in $100 \%$ dimethyl sulfoxide (Sigma Aldrich) and $5 \mathrm{FC}$ in sterile distilled water. All drug stock solutions were frozen at $-70^{\circ} \mathrm{C}$ as $100 \mathrm{x}$ stocks until used. The MICs were determined spectrophotometrically as follows: after $48 \mathrm{~h}$. incubation, the optical density of each well of the microtiter plate was read with a microplate reader (Bio-Rad) at $490 \mathrm{~nm}$. For AMB, the MIC endpoint was defined as the lowest drug concentration exhibiting a reduction in growth of $90 \%$ or more, compared with the control. For 5FC and the azole drugs, the MIC endpoint was defined as the concentration producing $50 \%$ inhibition (13). The breakpoints MICs was based on CLSI M27-A2 (7) reference microdilution method described for Candida sp. Experiments were repeated in duplicate, and MICs with one dilution higher were found and accepted as described by CLSI (7).

\section{RESULTS}

\section{Identification}

All isolates presented membranous and finely cerebriform, white to cream-colored colonies. Initial microscopic examination of portions of these colonies, as well as slide cultures, demonstrated round to oval, budding yeast-like cells and true hyphae forming cylindrical arthroconidia. They grew on SGA at 30 and $35^{\circ} \mathrm{C}$ but not at $45^{\circ} \mathrm{C}$. The overall micro- and macroscopic appearance was consistent with that for members of the genus Trichosporon and morphological, physiological, and biochemical features were as described for T. asahii.

\section{In vitro antifungal susceptibility testing}

The MICs of the four antimicrobial agents for the quality control organisms were consistently within 2 or 3 dilutions of each other. No differences were observed between MICs obtained by the CLSI reference procedure and those achieved by the modified method. The MICs of four antifungal drugs for the $T$. asahii isolates, obtained by the CLSI broth microdilution method, are presented in Table 1. As indicated, the isolates had reduced susceptibility in vitro to all drugs, showing 4-6 times higher MICs to itraconazole and 3-4 times to 5-flucytosine compared of MICs breakpoint values. FCZ exhibited the best activity in vitro against the majority of the isolates $(90 \%)$, with MIC of $16 \mu \mathrm{g} / \mathrm{mL}$ and only one isolate with $32 \mu \mathrm{g} / \mathrm{mL}$. Three isolates have MIC value for AMB above $2 \mu \mathrm{g} / \mathrm{mL}$.

\section{DNA fragment}

Both primers for the ITS region and TRR/TRF amplified all DNA isolates, producing distinct DNA fragments of approximately $530 \mathrm{bp}$ and $170 \mathrm{pb}$, respectively, as shown in Fig. 1.

\section{RAPD analysis}

In this study, each of the 10 isolates was analyzed with two individual primers, primer M13 and 6, by the RAPD method. All amplifications were repeated twice at least. The most intense bands were reproducible, even with different extracts of DNA from the same isolate. However, differences were observed in some low-intensity bands. Therefore, in comparative analyses, 
Table 1. Isolation sites and antifungal susceptibility test results for T. asahii isolates recovered from patients in an Intensive Care Unit.

\begin{tabular}{lcccc}
\hline \multirow{2}{*}{ Isolate } & \multicolumn{4}{c}{${\text { MIC }\left(\mathrm{mg} / \text { liter }^{\mathrm{a}}\right.}^{\mathrm{a}}$} \\
\cline { 2 - 5 } & FLZ & ITZ & 5FC & AMB \\
\hline 20 urine & 16 & 8 & 32 & 2 \\
22 urine & 32 & 4 & 32 & 2 \\
33 oral cavity & 16 & 2 & 32 & 4 \\
37 oral cavity & 16 & 2 & 16 & 2 \\
88 urine & 16 & 2 & 16 & 4 \\
91 urine & 16 & 4 & 32 & 2 \\
121 urine & 16 & 2 & 16 & 2 \\
131 urine & 16 & 2 & 16 & 4 \\
132 urine & 16 & 2 & 16 & 2 \\
134 urine & 16 & 2 & 16 & 2 \\
ATCC 22019 & $2-8$ & $0,06-0,25$ & $0,12-0,5$ & $0,25-1$ \\
(type strain) & & & & \\
Susceptibility & $\leq 8$ & $\leq 0.125$ & $\leq 4$ & $>2^{\mathrm{c}}$ \\
breakpoints $^{\mathrm{b}}$ & & & & \\
\hline
\end{tabular}

${ }^{a}$ Abbreviations: FLZ, fluconazole, ITZ, itraconazole, 5FC,5fluorocytosine, AMB, amphotericin $\mathrm{B}$; ${ }^{\text {T}}$ The breakpoints are based on NCCLS M27-A2 reference microdilution method described by

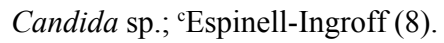

only high-intensity bands were used. Each primer generated between six and nine bands for an individual isolate.

Among the 10 isolates analyzed by primer 6, various RAPD profiles were observed with molecular weights of bands between 170 and $1100 \mathrm{bp}$. All visible and definite bands were included in the analysis (Fig. 2). Dendrogram analysis obtained with this random primer showed a high homogeneity among the isolates from different body sites, with five RAPD profiles. Only one group (A) was generated with a coefficient of similarity greater than $85 \%$. The largest (A1) contained seven isolates from urine, one grouped in a cluster (5 isolates) and two isolates with high degree $(>90 \%)$. The subgroup A2 grouped in a cluster contained two isolates from oral cavity and urine. Subgroups A1 and A2 were related by similarity coefficient above $85 \%$, suggesting these strains are closely related to each other. The isolate 33 from oral cavity has a low similarity coefficient of $70 \%$ in relation to the other groups, suggesting different strains.

For the primer M13 (Fig. 3), four different profiles were observed. One group was generated by a coefficient of similarity higher that $80 \%$. Two clusters were formed in the subgroup A1, the first with five isolates from urine and the second containing three isolates, two from urine and one from oral cavity. In this last cluster, the three isolates suggest colonization of different sites with the same strain. The subgroup A2 and the isolate 22
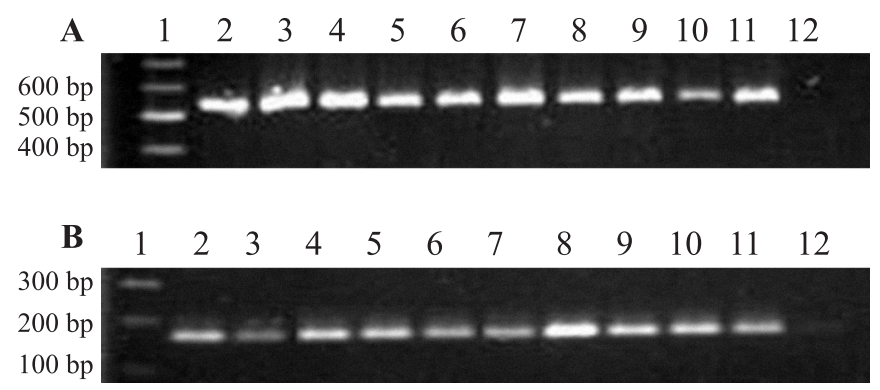

Figure 1. Agarose gel electrophoresis of PCR products of $T$. asahii isolates recovered from clinical specimens (oral cavity and urine) from patients in Intensive Care Units (ICU) using primers ITS1/ITS4 (A) and TRR/TRF (B). Lane 1- molecular size marker; lane 2- 20 urine; lane 3- 22 urine; lane 4- 33 oral cavity; lane 5- 37 oral cavity; lane 6- 88 urine; lane7- 91 urine; lane 8121 urine; lane 9-131 urine; lane 10- 132 urine; lane 11- 134 urine; lane 12- negative control.

from urine also presented a high degree of similarity with subgroup A1.

\section{DISCUSSION}

The total agreement between the identification of Trichosporon sp by PCR based on sequences of the Internal Transcribed Spacer Regions (ITS) and on the sequences of small-subunit (SSU) ribosomal DNA (rDNA) aligned by the primers TRF/TRR indicates that $T$. asahii can be readily identified by these two methods, as shown by Sugita et al. (51).

T. asahii has been isolated from various types of clinical specimens from immunocompromised patients, including blood, skin biopsy, and urine specimens $(9,17,19,29,32,43,52)$, but few were isolated from patients without immunological disorders (20). Factors that enhance mucosal colonization and subsequent invasion of Trichosporon species include broad-spectrum antibiotic treatment and scratches in mucosal barriers $(6,24,56)$.

Despite the increasing frequency and severity of trichosporonosis, data on the antifungal susceptibility of Trichosporon spp. are limited and recommendations for in vitro testing of this fungus are not included in the guidelines of the National Committee for Clinical Laboratory Standards (27). There are few data available regarding $T$. asahii susceptibility to antifungal drugs in Brazil. The emergence of $T$. asahii isolates with reduced susceptibility to common antifungal drugs is a matter for concern. In our study, all isolates had reduced susceptibility to AMB, 5-FC and azoles. ITZ and FCZ exhibited MICs of 2 to 8 and 16 to $32 \mu \mathrm{g} / \mathrm{ml}$, respectively. The first one corresponds to resistant isolates $(\leq 1)$ and for the $\mathrm{FCZ}$ intermediate susceptibility (16-32 $\left.\mu \mathrm{g} \mathrm{mL}^{-1}\right)$ based on CLSI breakpoints for Candida sp (7). For AMB, the controversy is 
greater, because we did not have MICs values that discriminated susceptible and resistant yeasts strains. Recently, EspinelIngroff (8) discussed the MIC value of $2 \mu \mathrm{g} \mathrm{mL}^{-1}$ as the breakpoint to filamentous fungus. Wolf et al. (58) reported the isolation of multidrug-resistant T. asahii from infected patients who exhibited risk factors and had developed either superficial infections or invasive infections while in ICU. Thus, the pathogenesis of Trichosporon infection in the ICU setting may

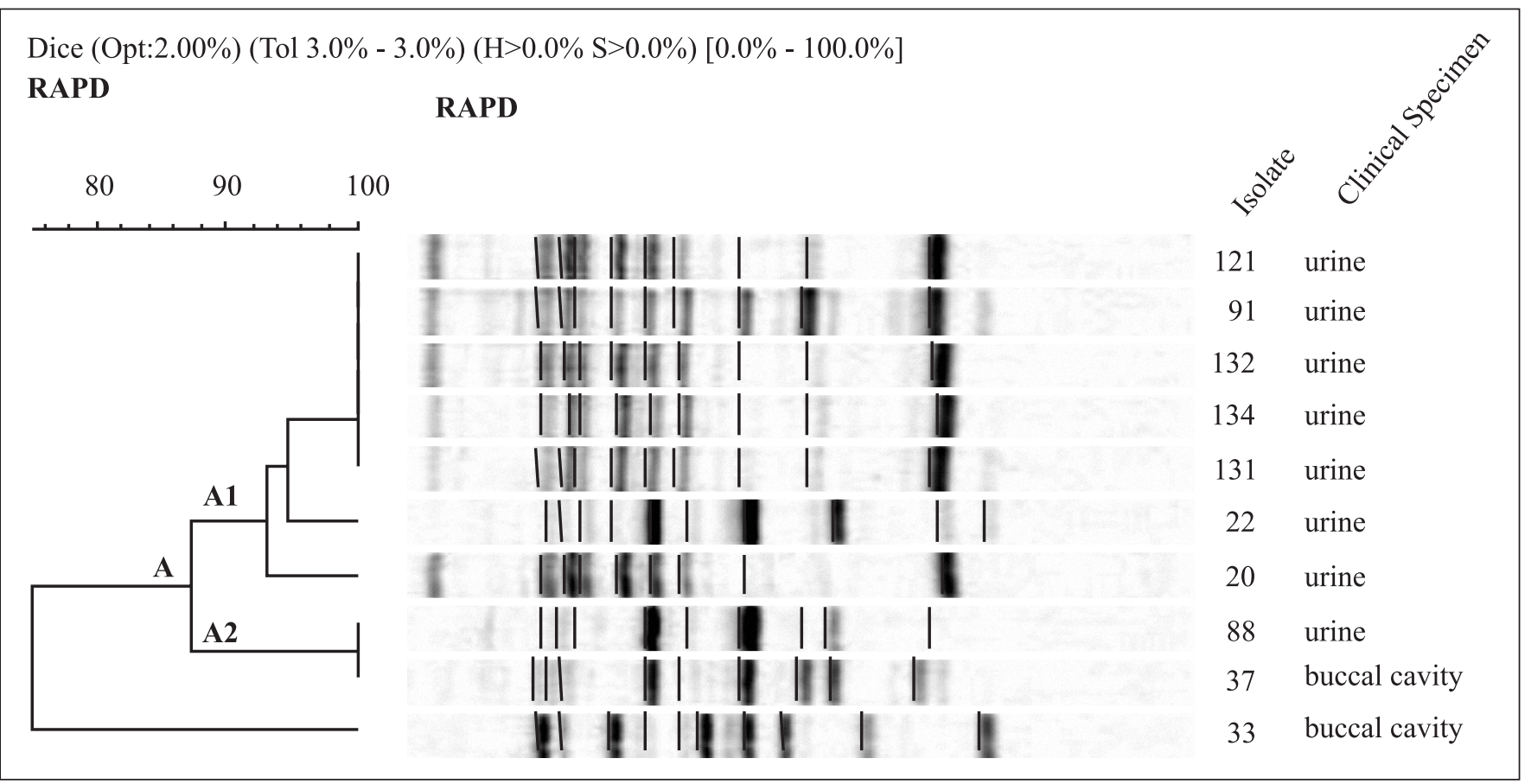

Figure 2. Dendrogram of T. asahii obtained from RAPD molecular patterns with primer 6.

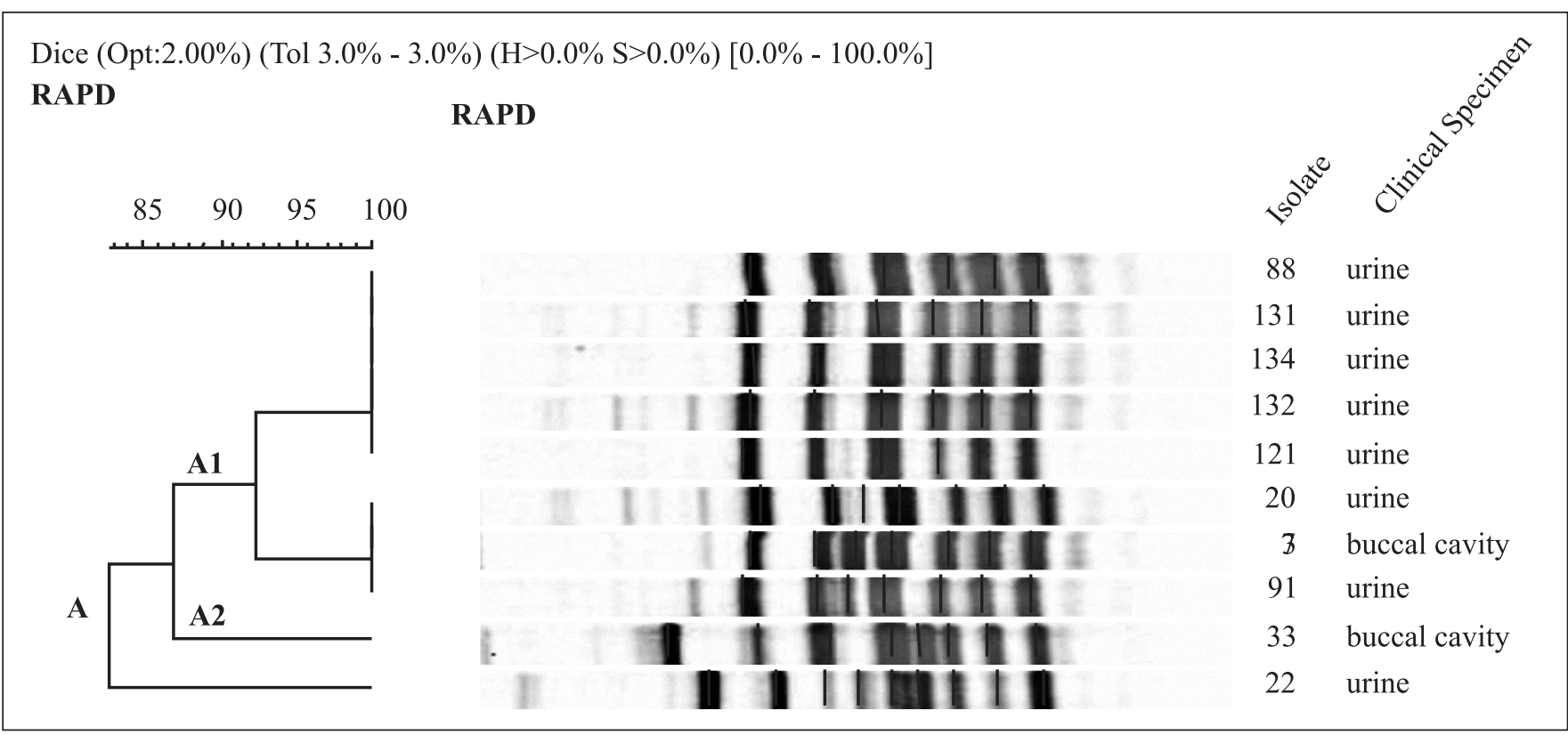

Figure 3. Dendrogram of T. asahii obtained from RAPD molecular patterns with primer M13. 
be similar to that of the more commonly observed Candida infection. Paphitou et al. (36) results confirmed the previous observation of Perparim et al. (37) as well as of other authors $(26,33,54,55)$ that the azoles, in general, appear to be more active in vitro against this pathogen than to AMB. Recently, a 47year-old man with diagnosed acute myeloblastic leukemia and non-insulin-dependent diabetes mellitus developed $T$. asahii fungemia and the in vitro antifungal susceptibilities showed high caspofungin and amphotericin B MICs values $(16 \mu \mathrm{g} / \mathrm{ml}$, and $>32 \mu \mathrm{g} / \mathrm{ml}$, respectively) while fluconazole, itraconazole, and voriconazole exhibited low MICs $(4 \mu \mathrm{g} / \mathrm{ml}, 0.5 \mu \mathrm{g} / \mathrm{ml}$, and $0.015 \mu \mathrm{g} / \mathrm{ml}$, respectively) (4). In another patient, a neutropenic individual with acute myeloid leukaemia experienced a breakthrough infection of T. asahii despite posaconazole treatment (42). Although there are no established breakpoints to define the antifungal susceptibility of Trichosporon spp, our study suggests the FCZ may be used to treat patients with trichosporonosis. McGinnis et al. (26), as well as in our study, also showed that $T$. asahii strains exhibited reduced susceptibility to AMB (MICs, 1 to $4 \mathrm{mg} /$ liter), but they were susceptible to ITZ and FCZ (MICs $=0.125$ to 1 and 0.5 to $4 \mathrm{mg} /$ liter, respectively). On the other hand, the FCZ MICs for two T.asahii isolates recovered from esophageal biopsy specimens of two patients were found to be relatively high and these isolates were also resistant to nystatin. Lemes et al. (23) verified that the isolates of T. asahii were 5FC susceptible, ITZ resistant and some isolates were resistance to FCZ. The in vitro resistance to antifungal drugs may not be critical in immunocompetent patients, who may overcome the infection when the precipitating cause (e.g., a catheter) is removed, even if only partial inhibition of fungal growth is achieved through the use of antifungal drugs. However, immunocompromised patients may be dependent on the action of fungicidal drugs, so that infection with multidrug-resistant Trichosporon species may be catastrophic in this population.

RAPD analysis with primers 6 and M13 generated a similar dendrogram structure. In general, there was, in both dendrograms, formation of groups containing strains with high similarities $(>0.8)$ among them associated with high MICs. The exception was strain 33 recovered from oral cavity, which showed minor similarity (around 0.7 ) with primer 6 , but high (> 0.85 ) with primer M13. Moreover, RAPD analysis suggested that the isolates the different body sites were similar, suggesting a common origin. In addition, these patients were hospitalized in ICU between April and December, revealing a possibly clonal source of infection.

In conclusion, a rapid and reliable identification of $T$. asahii was achieved by molecular techniques. In addition, RAPD can be used to differentiate genotypes and reveal the correlation among them, drug susceptibility and the origin of a strain. The higher correlation among genotypes and the higher MICs of these strains offer potential risks of exogenous nosocomial infection (e.g. to catheter). In addition, increasing use of antifungal drugs in the ICU may lead to the selection and isolation of more resistant species in the future.

\section{ACKNOWLEDGEMENTS}

This investigation was financially supported by the Brazilian Organizations, CNPq (Processo n. 400141/1998-1), FCF-UNESP and Instituto Adolfo Lutz.

\section{RESUMO}

\section{Diversidade genética e suscetibilidade a antifúngicos de Trichosporon asahii isolado de pacientes de Unidades de Terapia Intensiva}

Trichosporon asahii é um patógeno oportunista que apresenta altos índices de mortalidade em pacientes imunocomprometidos. No presente trabalho, dez cepas foram isoladas da cavidade bucal e urina de pacientes internados na Unidade de Terapia Intensiva (UTI) por seis meses. Todos os isolados foram identificados por métodos clássicos e moleculares, tipados por RAPD e testados in vitro quanto à sensibilidade ao fluconazol, itraconazol, 5-fluorocitosina e anfotericina B. Houve concordância total entre a identificação de Trichosporon sp por PCR baseado na seqüência da região ITS (Internal Transcribed Spacer) e na seqüência da subunidade menor do DNA ribossômico (rDNA). Os perfis genéticos foram determinados por RAPD utilizando dois iniciadores P6 e M13. A análise do dendrograma mostrou que a maioria das amostras apresentou alta similaridade entre elas $(>0.9)$ e todas foram multidrogas resistentes. Este estudo traz novos resultados em relação à identificação e genotipagem de isolados brasileiros de T. asahii em pacientes internados em UTI, bem como dados sobre o perfil de sensibilidade aos antifúngicos.

Palavras-chave: Trichosporon, PCR, RAPD, sensibilidade às drogas antifúngicas, drogas antifúngicas.

\section{REFERENCES}

1. Anaissie, E.J. (1992). Opportunistic mycoses in the immunocompromised host: experience at a cancer center and review. Clin. Infect. Dis., 14, 43-53.

2. Anaissie, E.J.; Hachem, R.; Karyotakis, N.C.; Gokaslan, A.; Kignani, M.C.; Stephens, L.C.; Tin, U.C. (1994). Comparative efficacies of amphotericin B, triazoles, and combination of both as experimental therapy for murine trichosporonosis. Antimicrob. Agents Chemother., 38, 2541-2544.

3. Arechavala, A.I.; Bianchi, M.H.; Robles, A.M.; Santiso, G.; Negroni, R. (2007). Identification and susceptibility against fluconazole and albaconazole of 100 yeasts' strains isolated from vaginal discharge. Rev. Iberoam. Micol., 24, 305-308. 
4. Bayramoglu, G.; Sonmez, M.; Tosun, I.; Aydin, K.; Aydin, F. (2008). Breakthrough Trichosporon asahii fungemia in neutropenic patient with acute leukemia while receiving caspofungin. Infection, 36, 68-70.

5. Carvalho, A.M.R.; Melo, L.R.B.; Moraes, V.L.; Neves, R.P. (2008). Invasive Trichosporon cutaneum infection in an infant with wilms' tumor. Braz. J. Microbiol., 39, 59-60.

6. Chan, R.M.; Lee, P.; Wroblewski, J. (2000). Deep-seated trichosporonosis in an immunocompetent patient: a case report of uterine trichosporonosis. Clin. Infect. Dis., 31, 621.

7. Clinical and Laboratory Standards Institute. (2002). Reference method for broth dilution antifungal susceptibility testing of yeasts. Approved standard document M27-A2. CLSI, Wayne, PA, USA.

8. Espinel-Ingroff, A. (2008). Mechanisms of resistance to antifungal agents: Yeasts and filamentous fungi. Rev. Iberoam. Micol., 25, 101106.

9. Fagundes Junior, A.A.; Carvalho, R.T.; Focaccia, R.; Fernandez, J.G.; Araújo, H.B.N.; Strabelli, T.M.V.; Kopel, L.; Lage, S.G. (2008). Trichosporon asahii an emerging etiologic agent of fungal infection and colonization in heart failure patients in intensive care unit: case report and literature review. Rev. Bras. Ter. Intensiva, 20, 106-109.

10. Fleming, R.V.; Walsh, T.J.; Anissie, E.J. (2002). Emerging and less common fungal pathogens. Infect. Dis. Clin. North Am., 16, $915-$ 933.

11. Fournier, S.; Pavageau, W.; Feuillhade, M.; Deplus, S.; Zagdanski, A.M.; Verola, O.; Dombret, H.; Molina, J.M. (2002). Use of voriconazole to successfully treat disseminated Trichosporon asahii infection in a patient with acute myeloid leukaemia. Eur. J. Clin. Infect. Dis., 21, 892-896.

12. Fujita, S.I.; Senda, Y.; Nakaguchi, S.; Hashimoto, T. (2001). Multiplex PCR using internal transcribed spacer 1 and 2 regions for rapid detection and identification of yeast strains. J. Clin. Microbiol., 39, 3617-3622.

13. Ghannoum, M.A.; Ibrahim, A.S.; Fu, Y.; Shafiq, M.C.; Edwards, J.E. Jr.; Criddle, R.S. (1992). Susceptibility testing of Cryptococcus neoformans: a microdilution technique. J. Clin. Microbiol., 30, 28812886.

14. Girmenia, C.; Pagano, L.; Martino, B.; D’Antonio, D.; Fancir Specchia, G.; Melillo, L.; Buelli, M.; Pizzarelli, G.; Venditti, M.; Martino, P.; Gimema Infection Program. (2005). Invasive infections caused by Trichosporon species and Geotrichum capitatum in patients with hematological malignancies: a retrospective multicenter study from Italy and review of the literature. J. Clin. Microbiol., 43, 1818-1828.

15. Guého, E.; de Hoog, G.S.; Smith, M. (1992). Neotypification of the genus Trichosporon. Antonie Leeuwenhoek, 61, 285-288.

16. Gueho, E.; Improvisi, L.; de Hoog, G.S.; Dupont, B. (1994). Trichosporon on humans: a practical account. Mycoses, 37, 3-10.

17. Itoh, T.; Hosokawa, R.; Kodhdera, U.; Toyazaki, N.; Asada, Y. (1996). Disseminated infection with Trichosporon asahii. Mycoses, 39, 195199.

18. Kamberi, P.; Asturo, T.; Takayoshi, T.; Massaru, N. (1998). Efficacy of amphotericin B and azoles alone and in combination against disseminated trichosporonosis in neutropenic mice. Chemoterapy, $44,55-62$.

19. Kataoka-Nishimura, S.; Akyama, H.; Saku, K.; Dkashiwa, M.; Mori, S.; Tanikawa, S.; Sakanaki, H.; Onozawa, Y. (1998). Invasive infection due to Trichosporon cutaneum in patients with hematologic malignancies. Cancer, 82, 484-487.

20. Kim, Y.J.; Kim, S.I.; Kim, Y.R.; Park, Y.M.; Park, Y.J.; Kang, M.W. (2007). Successful treatment of septic shock with purpura fulminans caused by Trichosporon asahii in an immunocompetent patient. Ann. Clin. Lab. Sci., 37, 366-369.

21. Kurtzman, C.P.; Fell, J.W. (1998). The yeasts: a taxonomic study. Elsevier, Amsterdam.
22. Lasker, B.; Page, L.S.; Lott, T.J.; Kobayashi, G.S. (1992) Isolation, characterization, and sequencing of Candida albicans repetitive element 2. Gene, 116, 51-57.

23. Lemes, R.M.S.; Colombo, A.L.; Resende, M.A. (2004). Perfil de susceptibilidade de Trichosporon spp. à anfotericina B e azólicos. Proceedings of the Brazilian Congress of the Mycology 4rd ed., Ouro Preto, p. 139

24. Lyman, C.A.; Garrett, K.F.; Pizzo, P.A.; Walsh, T. (1994). Response human polymorphonuclear leukocytes and monocytes to Trichosporon beigelli: host defense against an emerging opportunistic pathogen. J. Infect. Dis., 170, 1557-1565.

25. Martins-Diniz, J.N.; Silva, R.A.; Miranda, E.T.; Mendes-Giannini, M.J. (2005). Monitoring of airborne fungus and yeast species in a hospital unit. Rev. Saúde Pública, 39, 398-405.

26. McGinnis, M.R.; Pasarel, L.; Sutton, D.A.; Fothergill, A.W.; Cooper, C.R.; Rinaldi, M.G. (1998). In vitro activity of voriconazole against selected fungi. Med. Mycol., 36, 239-242.

27. Metin, D.Y.; Hilmioglu-Polat, S.; Hakim, F.; Inci, R.; Tumbay, E. (2005). Evaluation of the microdilution, Etest and disk diffusion methods for antifungal susceptibility testing of clinical strains of Trichosporon spp. J. Chemother., 17, 404-408.

28. Meyer, M.H.; Letscher-Bru, V.; Waller, J.; Lutz, P.; Marcellin, L.; Herbrech, R. (2002). Chronic disseminated Trichosporon asahii infection in a leukemic child. Clin. Infect. Dis., 15, 22-25.

29. Mirza, S.H. (1993). Disseminated Trichosporon beigelli infection causing skin lesions in a renal transplant patient. J. Infect., 27, 67-70.

30. Moretti-Branchini, M.L.; Fukushima, K.; Schreiber, A.Z.; Nishimura, D.; Papaiordanou, P.M.; Trabasso, P.; Tanaka, R.; Miyaji, M. (2001). Trichosporon species in bone marrow transplanted patients. Diag. Microbiol. Infect. Dis., 39, 161-164.

31. Nagai, H.; Yamakami, Y.; Hashimoto, A.; Tokimatsu, I.; Nasu, M. (1999). PCR detection of DNA specific for Trichosporon species in serum of patients with disseminated trichosporonosis. J. Clin. Microbiol., 37, 694-699.

32. Nakajima, M.; Sugita, T.; Mikami, Y. (2007). Granuloma associated with Trichosporon asahii infection in the lung: Unusual pathological findings and PCR detection of Trichosporon DNA. Med. Mycol., 18, $1-4$.

33. Nenoff, P.; Oswald, U.; Haustein, U.F. (1999). In vitro susceptibility of yeasts for fluconazole and itraconazole. Evaluation of a microdilution test. Mycoses, 42, 629-639.

34. Neves, R.J.; Cavalcanti, M.A.Q.; Chaves, G.M.; Magalhães, O.M.C. (2002). Trichosporon pullulans (Lidner) diddens \& lodder isolated from the oral cavity of AIDS patient. Braz. J. Microbiol., 33, 241242.

35. Nucci, M.; Pulcheri, W.; Spector, N.; Bueno, A.P.; Bacha, P.C.; Caiuby, M.J.; Derossi, A.; Costa, R.; Morais, J.C.; de Oliveira, H.P. (1995). Fungal infections in neutropenic patients. A 8-year prospective study. Rev. Inst. Med. Trop. Sao Paulo, 37, 397-406.

36. Paphitou, N.I.; Ostrosky-Zeichner, L.; Paetznick, V.L.; Rodriguez, J.R.; Chen, E.; Rex, J.H. (2002). In vitro antifungal susceptibilities of Trichosporon species. Antimicrob. Agents Chemother, 46, 1144-1146.

37. Perparim, K.; Nagai, H.; Hashimoto, A.; Goto, Y.; Tashiro, T.; Nasu, M. (1996). In vitro susceptibility of Trichosporon beigelli to antifungal agents. J. Chemother., 8, 445-448.

38. Pfaller, M.A.; Diekema, D.J. (2004). Rare and emerging opportunistic fungal pathogens: concern for resistance beyond Candida albicans and Aspergillus fumigatus. J. Clin. Microbiol., 42, 4419-4431.

39. Pini, G.; Faggi, E.; Donato, R.; Fanci, R. (2005). Isolation to Trichosporon in a hematology ward. Mycoses, 48, 45-49.

40. Pontes, Z.B.; Ramos, A.L.; Lima Ede, O.; Guerra, Mde. F.; Oliveira, N.M.; Santos, J.P. (2002). Clinical and mycological study of scalp white piedra in the State of Paraíba, Brazil. Mem. Inst. Oswaldo Cruz, 97, 747-750. 
41. Quindos, G.; Ruesga, M.T.; Martin-Mazuelos, E.; Salesa, R.; AlonsoVargas, R.; Carrillo-Munoz, A.J.; Brena, S.; San Milla, R.; Ponton, J. (2004). In vitro activity of 5-fluorocytosine against 1021 spanish clinical isolates of Candida and other medically important yeasts. Rev. Iberoam. Micol., 21, 63-69.

42. Rieger, C.; Geiger, S.; Herold, T.; Nickenig, C.; Ostermann, H. (2007). Breakthrough infection of Trichosporon asahii during posaconazole treatment in a patient with acute myeloid leukaemia. Eur. J. Clin. Microbiol. Infect. Dis., 26, 843-845.

43. Rodrigues, Gda. S.; de Faria, R.R.; Guazzelli, L.S.; Oliveira, Fde. M.; Severo, L.C. (2006). Nosocomial infection due to Trichosporon asahii: clinical revision of 22 cases. Rev. Iberoam. Micol., 23, 85-89.

44. Rodríguez-Tudela, J.L.; Martín-Díez, F.; Cuenca-Estrella, M.; Rodero, L.; Carpintero, Y.; Gorgojo, B. (2000). Influence of shaking on antifungal susceptibility testing of Cryptococcus neoformans: a comparison of the NCCLS standard M27A medium, buffered yeast nitrogen base, and RPMI-2\% glucose. Antimicrob. Agents Chemother., 44, 400-404.

45. Schwan, R.F.; Almeida, E.G.; Souza-Dias, M.A.; Jespersen, L. (2007). Yeast diversity in rice-cassava fermentations produced by the indigenous Tapirapé people of Brazil. FEMS Yeast Res., 7, 966-972.

46. Sneath, P.H.A.; Sokal, R.R. (1973) Numerical taxonomy: the principles and practice of numerical classification. W.H. Freeman and Company, San Francisco.

47. Stenderup, A.; Schonheyder, H.; Ebbesen, P.; Melbye, M. (1986). White piedra and Trichosporon beigelii carriage in homosexual men. J. Med. Vet. Mycol., 24, 401-406.

48. Sugita, T.; Ichikawa, T.; Matsukura, M.; Sueda, M.; Takashima, M.; Ikeda, R.; Nishikawa, A.; Shinoda, T. (2001). Genetic diversity and biochemical characteristics of Trichosporon asahii isolated from clinical specimens, houses of patients with summer-type hypersensitivity pneumonits, and environmental materials. J. Clin. Microbiol., 39, 2405-2411.

49. Sugita, T.; Nishikawa, A.; Ichikawa, T.; Ikeda, R.; Shinoda, T. (2000). Isolation of Trichosporon asahii from environmental materials. Med. Mycol., 38, 27-30.
50. Sugita, T.; Nishikawa, A.; Shinoda, T. (1998). Identification of Trichosporon asahii by PCR based on sequences of the internal transcribed spacer regions. J. Clin. Microbiol., 36, 2742-2744.

51. Sugita, T.; Nishikawa, A.; Shinoda, T. (1998). Rapid Detection of species of the opportunistic yeast Trichosporon by PCR. J. Clin. Microbiol., 36, 1458-1460.

52. Takamura, S.; Oono, T.; Kanzaki, H.; Arata, J. (1999). Disseminated trichosporonosis with Trichosporon asahii. Eur. J. Dermatol., 9, 577-579.

53. Toscano, C.M.; Jarvis, W.R. (1999). Emerging issues in nosocomial fungal infections. Curr. Infect. Dis., 1, 347-361.

54. Uchida, K.; Nishiyama, Y.; Okota, N.; Yamaguchi, H. (2000). In vitro antifungal activity of a novel lipopeptide antifungal agent, against various fungal pathogens. J. Antibiot. (Tokyo), 53, 11751181.

55. Uzun, O.; Arikan, S.; Docagoz, S.; Sancak, B.; Unai, S. (2000). Susceptibility testing of voriconazole, fluconazole, itraconazole and amphotericin B against yeast isolates in a Turkish University Hospital and effect of time of reading. Diag. Microbiol. Infect. Dis., 38, 2101-2107.

56. Walsh, T.J.; Lee, J.W.; Melcher, G.P.; Navarro, E.; Bacher, J.; Callender, D.; Reed, K.D.; Wu, T.; Lopez-Berestein, G.; Pizzo, P.A. (1992). Experimental Trichosporon infection in persistently granulocytopenic rabbits: implications for pathogenesis, diagnosis, and treatment of an emerging opportunistic mycosis. J. Infect. Dis., 28, 121-133.

57. Walsh, T.J.; Melcher, G.P.; Rinaldi, M.G.; Lecciones, J.; McGough, D.A.; Kelly, P.; Lee, J.; Callender, D.; Rubin, M.; Pizzo, A. (1990). Trichosporon beigelli, an emerging pathogen resistant to amphotericin B. J. Clin. Microbiol., 28, 1616-1622.

58. Wolf, D.G.; Falk, R.; Hacham, M.; Theelen, B.; Boekhout, T.; Scorzetti, G.; Shapiro, M.; Block, C.; Salkin, I.; Polacheck, I. (2001). Multidrug-resistant Trichosporon asahii infection of nongranulocytopenic patients in three intensive care units. J. Clin. Microbiol., 39, 4420-4425. 